\title{
Recombinant cellobiohydrolase of Myceliophthora thermophila: characterization and applicability in cellulose saccharification
}

Anica Dadwal', Shilpa Sharma ${ }^{1,2}$ and Tulasi Satyanarayana $a^{1,2^{*}}$

\begin{abstract}
A codon optimized cellobiohydrolase (CBH) encoding synthetic gene of 1188 bp from a thermophilic mold Myceliophthora thermophila (MtCel6A) was cloned and heterologously expressed in Escherichia coli for the first time. In silico analysis suggested that MtCel6A is a GH6 CBH and belongs to CBHII family, which is structurally similar to Cel6A of Humicola insolens. The recombinant MtCel6A is expressed as active inclusion bodies, and the molecular mass of the purified enzyme is $\sim 45 \mathrm{kDa}$. The $\mathrm{rMtCel} 6 \mathrm{~A}$ is active in a wide range of $\mathrm{pH}(4-12)$ and temperatures $\left(40-100^{\circ} \mathrm{C}\right)$ with optima at $\mathrm{pH} 10.0$ and $60^{\circ} \mathrm{C}$. It exhibits $\mathrm{T}_{1 / 2}$ of 6.0 and $1.0 \mathrm{~h}$ at 60 and $90^{\circ} \mathrm{C}$, respectively. The rMtCel6A is an extremozyme with organic solvent, salt and alkali tolerance. The $K_{m}, V_{m a x}, k_{c a t}$ and $k_{c a t} / K_{m}$ values of the enzyme are $3.2 \mathrm{mg} \mathrm{mL}^{-1}, 222.2 \mu \mathrm{mol} \mathrm{mg} \mathrm{min}^{-1}, 2492 \mathrm{~s}^{-1}$ and $778.7 \mathrm{~s}^{-1} \mathrm{mg}^{-1} \mathrm{~mL}^{-1}$, respectively. The product analysis of rMtCel6A confirmed that it is an exoenzyme that acts from the non-reducing end of cellulose. The addition of rMtCel6A to the commercial cellulase mix (Cellic CTec2) led to 1.9-fold increase in saccharification of the pre-treated sugarcane bagasse. The rMtCel6A is a potential CBH that finds utility in industrial processes such as in bioethanol, paper pulp and textile industries.
\end{abstract}

Keywords: Thermostable cellulose, Recombinant cellobiohydrolase, Alkalistable, Solvent tolerance, Extremozyme, Cellulose saccharification

\footnotetext{
*Correspondence: tsnarayana@gmail.com

1 Department of Biological Sciences \& Engineering, Netaji Subhas Institute of Technology (University of Delhi), Azad Hind Fauj Marg, Sector-3 Dwarka, New Delhi 110078, India

Full list of author information is available at the end of the article
} original author(s) and the source, provide a link to the Creative Commons licence, and indicate if changes were made. The images or other third party material in this article are included in the article's Creative Commons licence, unless indicated otherwise in a credit line to the material. If material is not included in the article's Creative Commons licence and your intended use is not permitted by statutory regulation or exceeds the permitted use, you will need to obtain permission directly from the copyright holder. To view a copy of this licence, visit http://creativecommons.org/licenses/by/4.0/. 


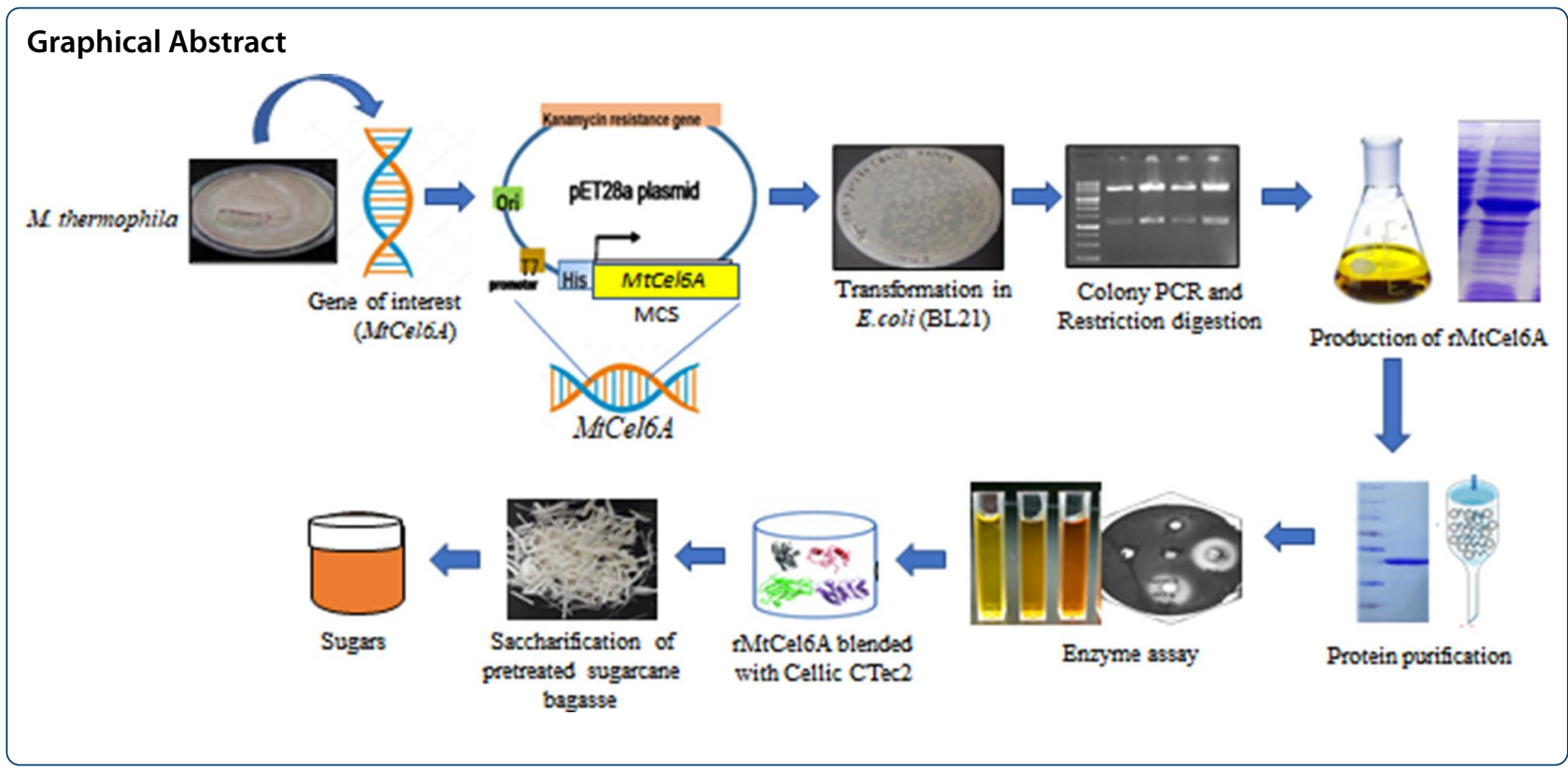

\section{Keypoints}

- MtCel6A has been cloned for the first time from Myceliophthora thermophila.

- It is a thermo-alkali stable enzyme with organic solvent and salt tolerance.

- This CBHII is compatible with Cellic CTec2 in improving cellulose saccharification.

\section{Introduction}

Lignocellulosic biomass is the abundant and renewable source of energy. In view of global warming and increasing demands for energy, the conversion of lignocellulosics to bioethanol is an attractive alternative (Liu et al. 2019). Lignocellulosics are predominantly composed of cellulose, hemicellulose and lignin. The enzymes that convert the complex and recalcitrant structure of cellulose are termed cellulases that includes three components cellobiohydrolase $(\mathrm{CBH})$, endoglucanase (EGL) and $\beta$-glucosidase (BGL) (Himmel et al. 1999). Cellobiohydrolases (CBHs) are further classified as $\mathrm{CBHI}$ and CBHII based on their mode of action. CBHI acts on reducing ends, while CBHII acts on non-reducing ends of oligosaccharides of varied length to produce cellobiose. All three enzymes act synergistically to saccharify cellulose (Horn et al. 2012). The sugars generated from the conversion process are further fermented to ethanol utilizing yeast strains such as Saccharomyces cerevisiae (Kang et al. 2014). According to the CAZy (Carbohydrate Active Enzymes) database (http://www. cazy.org), the cellulases are classified into different $\mathrm{GH}$ families. The hydrolytic enzymes are indispensable for biomass valorization (Manisha 2017). The CBHs typically belong to GH5-GH7, GH9 and GH48 families. The cellulases are produced naturally by various fungal, bacterial and archaeal species (Obeng et al. 2017) and the cellulases produced by thermophilic microbes are typically thermostable.

Thermostable enzymes are of immense interest because of various attractive features they offer, including the presence of activity at elevated temperatures, lower risk of contamination, ability to withstand high $\mathrm{pH}$ and organic solvents (Dadwal et al. 2021; Liu et al. 2019). The thermostable cellulases are in great demand in various biotechnological industries including bioethanol production (Suresh et al. 2021; Turner et al. 2007). Over the years, several investigations have been carried out for evolving efficient thermostable cellulases through various genetic/protein engineering techniques (Dadwal et al. 2020). To fulfil the immense demand for the thermostable cellulases for industrial applications, heterologous expression has become the crucial technique that often significantly improves protein expression levels (Lambertz et al. 2014). The formation of inclusion bodies (IBs) is, however, regarded as one of the limitations in recombinant protein production in Escherichia coli. In the last few years, the concept of IBs being only inactive protein aggregates has changed and the concept of non-classical IBs emerged (Slouka et al. 2019). There are certain advantages associated with these IBs such as their easy isolation and purification process, resistance to proteolytic degradation, mechanical stability, overexpression, native-like secondary structure of protein in IBs, and 
the presence of biological activity (Singhvi et al. 2020). A few studies have reported a high yield and activity of the recombinant proteins produced in IBs in contrast to the recombinant proteins secreted under optimal conditions (Gundinger and Spadiut 2017; Jong et al. 2017).

Myceliphthora thermophila (syn. Thermothelomyces thermophilus, Sporotrichum thermophile) is a thermophilic mold that grows optimally at $45{ }^{\circ} \mathrm{C}$ (Morgenstern et al. 2012). This mold is a source of a series of glycoside hydrolases including cellulases. There are eight $\mathrm{CBHs}$ in the genome of this mold, but only two of them have been cloned and characterized (Gusakov et al. 2005; Kadowaki et al. 2018); both of them belong to the GH7 family. The investigations on GH6 cellobiohydrolases have not been reported often. However, a few GH6 cellulases have been explored, such as those of Cellulosimicrobium funkei CelL (Kim et al. 2016), Thermobifida halotolerans GH6 endoglucanase (Yin et al. 2015) and Thermobifida fusca Cel6A (Ali et al. 2015).

In this investigation, a GH6 cellobiohydrolase gene of M. thermophila (MtCel6A) was cloned, expressed and characterized for the first time. All fungal GH6 and GH7 $\mathrm{CBHs}$ are classified as $\mathrm{CBHII}$ and $\mathrm{CBHI}$, respectively (Teter et al. 2014), and MtCel6A belongs to CBHII family that acts from the non-reducing ends of cellulose chains. The synthetic gene (MtCel6A) was heterologously expressed in E. coli. The recombinant enzyme is produced in the form of non-classical inclusion bodies (IBs), which is further solubilized, refolded, purified and characterized. The rMtCel6A is tolerant to various organic solvents and metal ions. It exhibits a good detergent and salt tolerance too. Moreover, we found that it efficiently degrades crystalline cellulosic biomass such as sugarcane bagasse, and the hydrolysis product mainly is cellobiose. Furthermore, the synergistic action of rMtCel6A with a commercial cellulase cocktail (Cellic CTec2) on the pretreated sugarcane bagasse has also been confirmed. This study suggests that the recombinant MtCel6A is a good biocatalyst of commercial value in the various biotechnological processes where alkaline conditions prevail in the saccharification of alkali-pretreated lignocellulosic biomass.

\section{Materials \& methods}

\section{Microbial strains, plasmids and reagents}

E. coli DH5 $\alpha$ and E. coli BL21 (DE3) were used for plasmid replication and expression in host cells, respectively. Both these strains were procured from Invitrogen (CA, USA). The Luria-Bertani (LB) medium purchased from Hi-Media (Mumbai, India) was used for maintaining the strains. The pET-28a vector (Invitrogen, USA) was used as a cloning and expression vector. Restriction enzymes and the DNA ligation kit were procured from New England Biolabs (MA, USA). For determining the enzyme activity, all the substrates were bought from Sigma (USA). Cellic CTec2 was supplied by Novozymes (Bagsværd, Denmark). All other reagents used were of analytical grade and purchased from Sigma (St. Louis, USA), Merck (Darmstadt, Germany), Fisher Scientific (Massachusetts, USA), CDH (India) and SRL (India) and Hi-Media (Mumbai, India). Sugarcane bagasse used in the study was collected from a local juice shop.

\section{In silico analysis of MtCel6A}

The 3D protein model of MtCel6A was constructed using Swiss-Model, (https://swissmodel.expasy.org/) an online tool of Expasy. The protein sequence similar to MtCel6A was retrieved using BLAST-P (Basic Local Alignment Search Tool for Proteins) program (https://blast.ncbi. nlm.nih.gov/Blast.cgi). Multiple sequence alignments were made using ESPript 3.0 (https://espript.ibcp.fr/).

\section{Construction of MtCel6A expression vector}

The Cel6A gene of $M$. thermophila syn. Thermothelomyces thermophilus (accession number AEO59280.1) with Codon Adaptation Index (CAI) of 0.67 was codon optimized to CAI of 0.88 for expression in E. coli (GenBank accession no. MZ826702). The synthetic codon optimized gene was synthesized and supplied by Biomatik (Canada). Gene-specific primers (FP: $5^{\prime}$ GGCGGATCC ATGAAATTTGTTCAGAGCGC $3^{\prime}$ and RP: $5^{\prime}$ CGC AAGCTCTTAAAAGCTCGGATTGGC $3^{\prime}$ ) were used for amplifying MtCel6A (1188 bp). The double digestion of amplified MtCel6A and pET-28a was carried out using BamHI and HindIII to generate sticky ends and were ligated using ligation kit. The ligated product was further transformed into $E$. coli DH5 $\alpha$. Kanamycin resistant $E$. coli colonies were selected on LB supplemented with $50 \mu \mathrm{g} \mathrm{mL}^{-1}$ kanamycin (GoldBio, USA).The positive colonies harbouring $r M t C e l 6 A$-pET-28a were confirmed by colony PCR and double digestion of the plasmid with BamHI and HindIII. The pET-28a plasmid containing MtCel6A was transformed into chemically competent E. coli BL21 (DE3). The recombinant MtCel6A was produced from positive clones.

\section{Production of rMtCel6A}

For the expression of recombinant MtCel6A, E. coli BL21 (DE3) harbouring pET-28a-MtCel6A was cultivated in $1 \mathrm{~L} \mathrm{LB}$ medium (supplemented with $50 \mu \mathrm{g} \mathrm{mL}$ kanamycin) and grown at $37{ }^{\circ} \mathrm{C}$ to the optical density $(\lambda-600 \mathrm{~nm})$ of 0.5 . The gene expression was induced by $0.25 \mathrm{mM}$ isopropyl $\beta$-D-1-thiogalactopyranoside (IPTG) at $30{ }^{\circ} \mathrm{C}$. The cells were harvested after $2 \mathrm{~h}$ by centrifugation $\left(8,000 \mathrm{rpm}\right.$ for $20 \mathrm{~min}$ at $\left.4{ }^{\circ} \mathrm{C}\right)$. The resultant cell pellet was washed with Tris- $\mathrm{HCl}$ buffer $(\mathrm{pH} 8.0)$ and 
resuspended in $10 \mathrm{~mL}$ lysis buffer $[50 \mathrm{mM}$ Tris- $\mathrm{HCl}(\mathrm{pH}$ 8.0), $300 \mathrm{mM}$ sodium chloride $(\mathrm{NaCl}), 1 \%$ triton $\mathrm{X}-100$, $1 \mathrm{mM}$ phenylmethylsulfonyl fluoride (PMSF)]. The cell suspension was sonicated to disrupt the cells following sonication cycles of $5 \mathrm{~s}$ on and $5 \mathrm{~s}$ off for $20 \mathrm{~min}$. The lysate was centrifuged $\left(12,000 \mathrm{rpm}\right.$ for $30 \mathrm{~min}$ at $\left.4{ }^{\circ} \mathrm{C}\right)$ and the pellet was stored at $-20^{\circ} \mathrm{C}$ for isolating IBs.

\section{Isolation, solubilization and refolding of $\mathrm{rMtCel} 6 \mathrm{~A}$ from inclusion bodies}

The isolation and purification of IBs from cell pellet was performed according to Palmer and Wingfield (2012). For solubilization of IBs, six solubilization buffers were used: [Buffer 1 (B1): Tris buffer (pH 10.0), Buffer 2 (B2): Tris buffer $(\mathrm{pH} 10.0)+5 \%$ dimethylsulfoxide (DMSO), Buffer 3 (B3): Tris buffer (pH 11.0), Buffer 4 (B4): Tris buffer (pH 11.0) + 5\% DMSO, Buffer 5 (B5): Tris buffer ( $\mathrm{pH} 12.5)$, Buffer 6 (B6): Tris buffer (pH 12.5) +5\% DMSO]. After solubilization, the samples were centrifuged $(12,000 \mathrm{rpm}$ for $15 \mathrm{~min}$ at $4{ }^{\circ} \mathrm{C}$ ) and the supernatants were loaded on $12 \%$ SDS PAGE to analyse the protein. The solubilization was assessed in terms of turbidity and total protein content by recording absorbance at 600 and $280 \mathrm{~nm}$, respectively. Solubilization (\%) was calculated by solubilizing IBs $\left(1 \mathrm{mg} \mathrm{mL}^{-1}\right)$ in different buffers and determining protein content in supernatant by Lowry's method (Waterborg 2009). The solubilized rMtCel6A IBs were refolded by pulsatile renaturation process using refolding buffer [50 mM Tris- $\mathrm{HCl}$ (pH 10.0), 10\% glycerol, $5 \mathrm{mM}$ dithiothreitol (DTT), $1 \mathrm{mM}$ PMSF] in $1: 9$ ratio at $4{ }^{\circ} \mathrm{C}$ with constant agitation. The refolded rMtCel6A protein was further concentrated using Amicon centrifugal filters with $30 \mathrm{kDa}$ molecular weight cut-off.

\section{Purification of rMtCel6A}

After refolding, the purification of rMtCel6A was performed from IBs according to the manufacturer's instructions (Qiagen, Germany). The proteins were eluted with an increasing gradient of imidazole concentration (50$150 \mathrm{mM}$ ). The purified protein was stored at $4{ }^{\circ} \mathrm{C}$ and the purity of the enzyme was checked by electrophoresis on $12 \%$ SDS-PAGE. Protein concentration of the purified rMtCel6A was determined by the Lowry's method with bovine serum albumin (BSA) as the standard.

\section{Zymogram analysis}

For detection of $\mathrm{CBH}$ activity of rMtCel6A, zymogram analysis was performed. The purified rMtCel6A was run on a $12 \%(\mathrm{w} / \mathrm{v})$ Native-PAGE. At the end of the electrophoresis, the gel was rinsed and equilibrated with buffer ( $\mathrm{pH}$ 10.0). Subsequently, the gel was overlaid on $2.5 \mu \mathrm{M}$ 4-methylumbelliferyl $\beta$-D-cellobioside (4-MUC) (a fluorescent substrate) agar plate and incubated in dark for
$30 \mathrm{~min}$ at $50{ }^{\circ} \mathrm{C}$, followed by visualizing of the plate under UV light for detecting fluorescence due to the release of 4-methylumbelliferone.

\section{Qualitative and quantitative cellobiohydrolase assay}

For qualitative assay of $\mathrm{CBH}, 2.5 \mu \mathrm{M}$ of 4-MUC was used along with $1 \%$ agarose in buffer $(\mathrm{pH} 10.0)$ and poured into Petridish. After solidifying, the wells were punched and various fractions of rMtCel6A $(200 \mu \mathrm{l})$ were dispensed into these wells. The Petridish was incubated in dark for $60 \mathrm{~min}$ at $50{ }^{\circ} \mathrm{C}$. The fluorescence was observed under UV light.

For quantitative detection of $\mathrm{CBH}$ activity, the reaction mixture containing $0.5 \mathrm{~mL}$ substrate $[0.5 \%(\mathrm{w} / \mathrm{v})$ Avicel $\mathrm{PH}-101$ prepared in $0.1 \mathrm{M}$ buffer $(\mathrm{pH} \mathrm{10.0)}$ and $0.5 \mathrm{~mL}$ appropriately diluted enzyme (rMtCel6A) was incubated at $60{ }^{\circ} \mathrm{C}$ for $30 \mathrm{~min}$. After completion of hydrolysis, $1 \mathrm{~mL}$ of dinitrosalicylic acid (DNS) reagent was added to the reaction mixture and incubated at $100{ }^{\circ} \mathrm{C}$ for $10 \mathrm{~min}$. The reducing sugars liberated were quantitated by reading absorbance at $540 \mathrm{~nm}$ (Miller 1959). One unit of cellobiohydrolase is defined as the amount of enzyme that liberates $1 \mu \mathrm{mol}$ of reducing sugars as glucose $\min ^{-1}$ under the assay conditions.

\section{Circular dichroism spectroscopy}

Far-UV circular dichroism (CD) spectra of purified rMtCel6A in buffer were recorded in the range 190-260 nm in a Jasco J-815 Spectropolarimeter (Jasco International Co.) using a $1 \mathrm{~mm}$ quartz cuvette at scanning speed, band width, and digital integration time (D.I.T) of $100 \mathrm{~nm} \mathrm{~min} \mathrm{~min}^{-1}, 1 \mathrm{~nm}$, and $1 \mathrm{~s}$, respectively. A total of 3 spectra were collected, averaged and corrected by subtracting the blank. The results are expressed as CD signal (measured ellipticity) in mdeg (millidegrees).

\section{Substrate specificity of rMtCel6A}

To study substrate specificity of rMtCel6A, different substrates [carboxymethylcellulose (CMC), avicel, filter paper, cotton, microcrystalline cellulose (MCC) and birchwood xylan] were used. Enzyme activity was determined using DNS reagent (Miller 1959).

\section{Biochemical characterization of purified rMtCel6A Determination of optimum $\mathrm{pH}$ and temperature}

The purified rMtCel6A and $0.5 \%(\mathrm{w} / \mathrm{v})$ avicel was prepared in buffers of varying $\mathrm{pH}(0.1 \mathrm{M}, \mathrm{pH} 4.0-10.0)$. The enzyme reaction was carried out to determine the $\mathrm{pH}$ optimum. The optimum temperature for rMtCel6A was derived from the enzyme assays performed at varied temperatures $\left(40-100{ }^{\circ} \mathrm{C}, \mathrm{pH} 10.0\right)$ for $30 \mathrm{~min}$ with $0.5 \%$ avicel. The reducing sugars liberated were quantitated. 


\section{Determination of thermostability}

The enzyme was incubated at various temperatures (60$100{ }^{\circ} \mathrm{C}$ ) for varied time intervals to determine the thermostability. The aliquots were taken at the desired time intervals and kept in ice for an hour, followed by enzyme assay at $60^{\circ} \mathrm{C}$.

\section{Enzyme kinetics of rMtCel6A}

Kinetic parameters were evaluated from purified rMtCel6A by incubating the enzyme at $60{ }^{\circ} \mathrm{C}$ with different concentrations of avicel $\left(5-30 \mathrm{mg} \mathrm{mL}^{-1}\right)$ in $0.1 \mathrm{M}$ of sodium carbonate-bicarbonate buffer $(\mathrm{pH}$ 10.0). A Lineweaver-Burk graph was plotted to calculate Michaelis constant $\left(\mathrm{K}_{\mathrm{m}}\right)$ and the maximum enzyme action velocity $\left(\mathrm{V}_{\max }\right)$ values. The turnover number $\left(\mathrm{k}_{\mathrm{cat}}\right)$ values were calculated from $V_{\max }$ and the molar enzyme concentration used in the reaction. The catalytic efficiency was calculated by dividing $\mathrm{k}_{\text {cat }}$ with $\mathrm{K}_{\mathrm{m}}$ value.

\section{Effect of metal ions, organic solvents, detergents and enzyme inhibitors on the activity of $r M t C e l 6 A$}

The purified recombinant enzyme was incubated with avicel in the presence of different metal ions $(5 \mathrm{mM}$ of $\mathrm{Na}^{+}, \mathrm{Ca}^{2+}, \mathrm{Co}^{2+}, \mathrm{K}^{+}, \mathrm{Mg}^{2+}, \mathrm{Mn}^{2+}, \mathrm{Fe}^{2+}, \mathrm{Cu}^{2+}, \mathrm{Zn}^{2+}$, $\mathrm{NH}_{4}{ }^{+}$), organic solvents (acetone, butanol, chloroform, ethanol, ethyl acetate, hexane, isoamyl-alcohol, isopropanol, liquor ammonia and methanol) at $10 \%(\mathrm{v} / \mathrm{v})$, detergents such as sodium dodecyl sulphate (SDS), tween-80, triton X-100, cetyltrimethylammonium bromide (CTAB), and polyethylene glycol (PEG) at $0.5 \%(\mathrm{w} / \mathrm{v})$ and different modulators (5.0 mM concentration) such as iodoacetamide (IA), diethylpyrocarbonate (DEPC), dithiothreitol (DTT), ethyl-3-(3-dimethyl aminopropyl) carbodiimide (EDAC), ethylenediaminetetraacetic acid (EDTA), N-bromosuccinimide (NBS), PMSF, Woodward's reagent $\mathrm{K}$ (WRK). The activity of the enzyme under standard assay conditions without any additives was considered as the control with $100 \%$ enzyme activity.

\section{Effect of $\mathrm{NaCl}$}

The purified recombinant enzyme was incubated with avicel in the presence of varying concentrations of $\mathrm{NaCl}$ $(0.5-3 \mathrm{M})$ at $60^{\circ} \mathrm{C}$ for $30 \mathrm{~min}$. The enzyme activity was quantified in each sample.

\section{Utility of rMtCel6A in saccharification of pre-treated sugarcane bagasse}

The sugarcane bagasse was washed thoroughly with tap water and later with distilled water. The residue was cut into 1-2 inch pieces and pre-treated with sodium sulphite $\left(\mathrm{Na}_{2} \mathrm{SO}_{3}\right)$. After pretreatment, it was further washed to neutral $\mathrm{pH}$, dried and ground to 30 mesh size for hydrolysis. The biomass loading of $4 \%(\mathrm{w} / \mathrm{v})$ with 50 units of pure rMtCel6A were added to $10 \mathrm{~mL}$ buffer $(\mathrm{pH}$ 10.0) followed by saccharification at $60{ }^{\circ} \mathrm{C}, 150 \mathrm{rpm}$ for $6 \mathrm{~h}$. The rMtCel6A was also used in various ratios with appropriately diluted commercial enzyme cocktail (Cellic CTec2) in order to study their synergistic effect. The reducing sugars thus liberated were quantitated in the hydrolysates using DNS reagent (Miller 1959). The products of enzymatic hydrolysis were examined by spotting the supernatant on pre-coated silica gel thin layer chromatographic (TLC) plates (60 F254, Merck). The mobile phase of butanol: acetone:/water (5:3:2) was used. The products were detected by spraying the plate with diphenylaniline reagent followed by air drying and exposure to $100{ }^{\circ} \mathrm{C}$ for 5 min (Anderson et al. 2000).

The \% saccharification and degree of synergy (DOS) were calculated using the following formulae (1) and (2), respectively:

$$
\begin{aligned}
& \text { Saccharification }(\%) \\
& =\frac{\text { Amount of reducing sugar liberated }(\mathrm{mg}) \times 0.9 \times 100}{\text { total cellulose content in the biomass }(\mathrm{mg})} \\
& \text { DOS }=\frac{\text { total sugars released from enzyme mix }}{\text { total sugars released from individual enzymes }}
\end{aligned}
$$

DOS $>1.0$ and DOS $\leq 1.0$ depict the status of synergy and no synergy/competition, respectively among the enzymes tested.

All experiments have been performed in triplicate, and the observations are presented as average values with standard deviation.

\section{Results}

\section{D model and catalytic amino acid residue of MtCel6A}

BLAST-P analysis revealed that MtCel6A belongs to GH6 family that exhibits similarity with the GH6 CBHs of Trichoderma reesei (51\%), Humicola insolens (53.7\%) and Chaetomium thermophilum (52.5\%). The 3D model of MtCel6A generated using Cel6A of $H$. insolens (PDB ID: 4I5R) as template that displayed maximum (54.18\%) sequence identity. The 3D-model comprises 7 -stranded $(\beta / \alpha)$ barrel fold and a tunnel shape catalytic site [Fig. 1a, b].

From multiple sequence alignment [Fig. 1c], various conserved regions were identified. Asp 128 identified as a catalytic acid that act as proton donor and Asp 314 may be a catalytic base. The amino acid residue Asp 83 is suggested to play a role in protonation of Asp 128 (Rouvinen et al. 1990). A few conserved short peptides, highlighted in red box in Fig. 1c, have also been identified. 
(a)

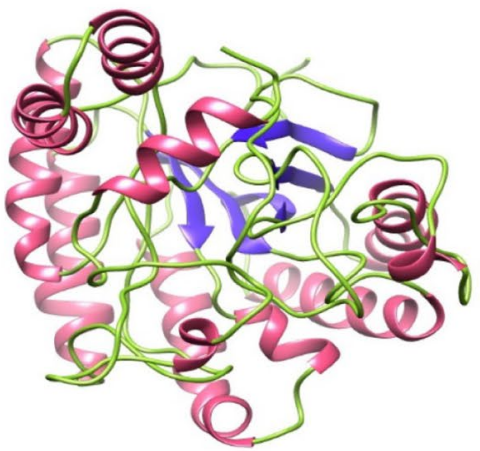

(b)

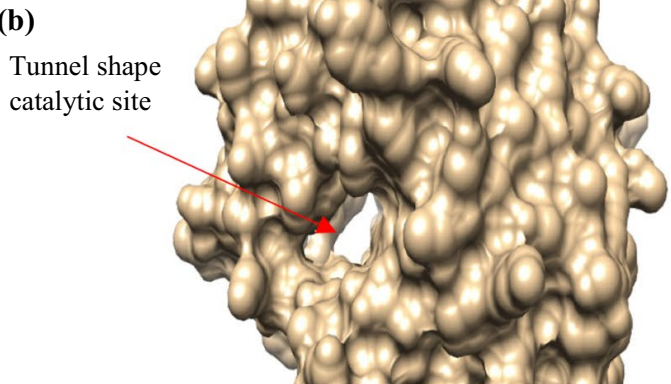

(c)
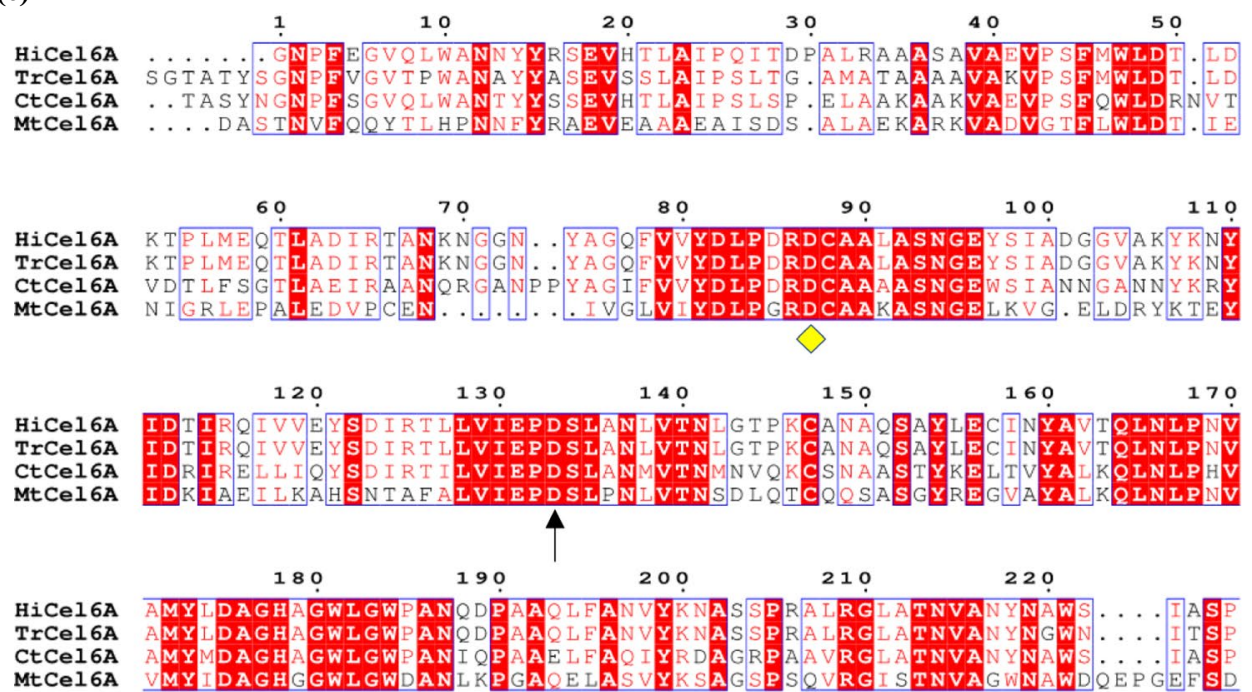

CtCel6A

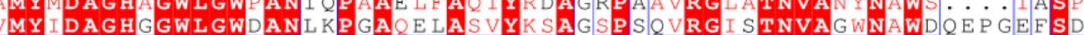
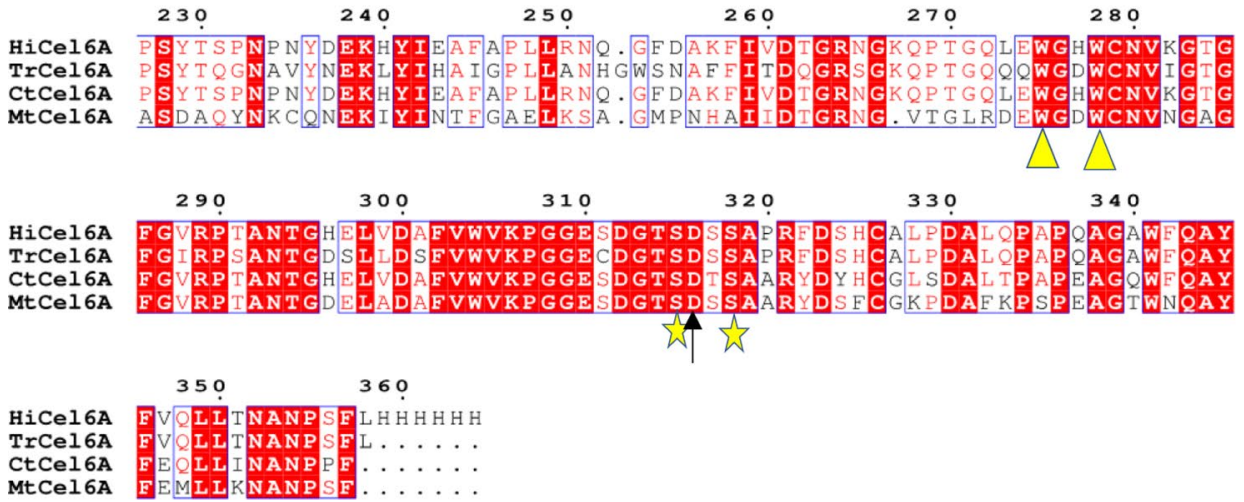

Fig. 1 a 3D model of MtCel6A; where a-helix, $\beta$-sheets and loops are highlighted in purple, blue and green, respectively. b 3D structure showing tunnel shape catalytic site. c Multiple sequence alignment of MtCel6A showing conserved critical amino acid residues; Asp 128 (catalytic acid) and Asp 314 (catalytic base) are marked with arrows, and other key residues (described in text) are marked with yellow diamond, triangle, and star

\section{Production of rMtCel6A}

The MtCel6A (synthesized gene) was amplified from the synthetic plasmid. Further, the cloning of synthetic
MtCel6A in pET-28a vector was confirmed by double digestion of the vector. During the recombinant enzyme expression in E. coli, the enzyme was not detected in the 


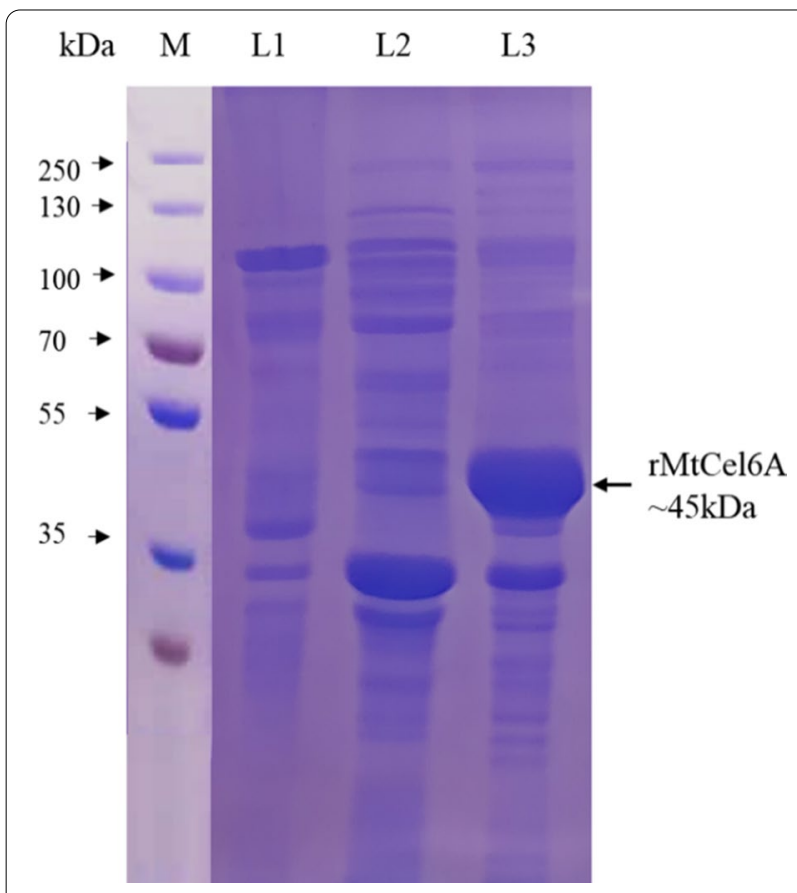

Fig. 2 Production of rMtCel6A under optimum conditions. The protein samples loaded on 12\% SDS PAGE; M: protein marker; L1: Empty vector (without construct) L2: rMtCel6A (supernatant); L3: rMtCel6A (pellet). [Protein ladder (PageRuler Plus prestained) was procured from Thermo Scientific]

soluble fraction obtained following E. coli cell lysis. The rMtCel6A accumulates in the bacterial IBs (Fig. 2) which were solubilized and refolded in order to obtain active enzyme. The enzyme production attained was about $6000 \mathrm{U} \mathrm{L}^{-1}$.

\section{Solubilization and refolding of rMtCel6A inclusion bodies}

The observations suggested that buffer $\mathrm{B} 6 \quad[\mathrm{pH}$ (12.5) + 5\% DMSO] facilitates the maximum solubilization of rMtCel6A IBs. Thus, B6 was selected based on high solubilization and high protein content attained in the supernatant [Fig. 3a, b].

\section{Purification of the rMtCel6A}

The predicted mass of MtCel6A is $42 \mathrm{kDa}$ as calculated using Protparam tool of Expasy (https://web.expasy. org/protparam/). However, the rMtCel6A was purified to homogeneity from solubilized and refolded IBs, the enzyme was of $\sim 45 \mathrm{kDa}$ protein at twofold purification, $57 \%$ yield and specific activity of $172 \mathrm{U} \mathrm{mg}^{-1}$ (Table 1). A little higher mass of the purified enzyme was recorded. By affinity chromatography, the protein was eluted at $120 \mathrm{mM}$ imidazole and the purity was confirmed by SDS-PAGE [Fig. 4 (a)]. The zymogram analysis of the purified rMtCel6A exhibited fluorescence under UV light. [Fig. 4 (a)].

\section{Enzyme assays}

The enzyme activity in various fractions of rMtCel6A was assessed qualitatively [Fig. 4b]. The high fluorescence was observed in well no. 4 which contained refolded IBs, while well no. 3 contained unfolded IBs which displayed comparatively low fluorescence. As depicted in Table 1, the refolded rMtCel6A displayed 1.23-fold enhanced enzyme activity in comparison with the unfolded enzyme. The purified enzyme exhibited specific activity of $85 \mathrm{U} \mathrm{mg}^{-1}$.

\section{Secondary structure of the enzyme}

The secondary structure of refolded rMtCel6A comprised $26.5 \% \alpha$-helix, $5.9 \% \beta$-strands, $31.9 \%$ turns and $35.7 \%$ random coils, while the secondary structure composition of unfolded rMtCel6A IBs displayed $22.9 \%$ $\alpha$-helix, $26.1 \%$ turns and $51 \%$ random coils, with no detectable $\beta$-strands (Additional file 1: Fig. S1).

\section{Substrate specificity}

The substrate specificity of rMtCel6A on various substrates is shown in Table 2. It is evident that MtCel6A is highly efficient on the microcrystalline cellulose depolymerization of avicel as compared to crystalline cellulose and filter paper with specific activity values 172 , 160 and $146 \mathrm{U} \mathrm{mg}^{-1}$, respectively with $>85 \%$ relative activity on all three substrates. However, it exhibits a low relative activity on cotton and wheat bran.

\section{Biochemical characteristics of rMtCel6A Optimum $\mathrm{pH}$ and temperature, and thermal stability}

The rMtCel6A is active in a broad range of $\mathrm{pH}$ (5.0 to 12.0) with optimum of 10.0 [Fig. 5a]. It is a thermostable enzyme with temperature optima of $60{ }^{\circ} \mathrm{C}$ [Fig. 5b]. The enzyme retained over $60 \%$ activity between $50-80{ }^{\circ} \mathrm{C}$. At 90 and $100{ }^{\circ} \mathrm{C}$, rMtCel6A retained 45 and $20 \%$ activity, respectively. The rMtCel6A displays activity at varied temperatures [Fig. 5c] and it exhibits $\mathrm{T}_{1 / 2}$ of $7,6,4,3.5$, 1.0 and $0.2 \mathrm{~h}$ at $50,60,70,80,90$ and $100{ }^{\circ} \mathrm{C}$, respectively.

\section{Enzyme kinetics}

rMtCel6A exhibited a $K_{m}$ of $3.2 \mathrm{mg} \mathrm{mL}^{-1}, \mathrm{~V}_{\max }$ of $222.2 \mu \mathrm{M} \mathrm{mg}^{-1} \mathrm{~min}^{-1}, \mathrm{k}_{\text {cat }}$ of $2491.8 \mathrm{~s}^{-1}$ and catalytic efficiency $\left(\mathrm{k}_{\mathrm{cat}} / \mathrm{K}_{\mathrm{m}}\right)$ of $778.68 \mathrm{~s}^{-1} \mathrm{mg}^{-1} \mathrm{~mL}^{-1}$, when avicel was used as the substrate. 

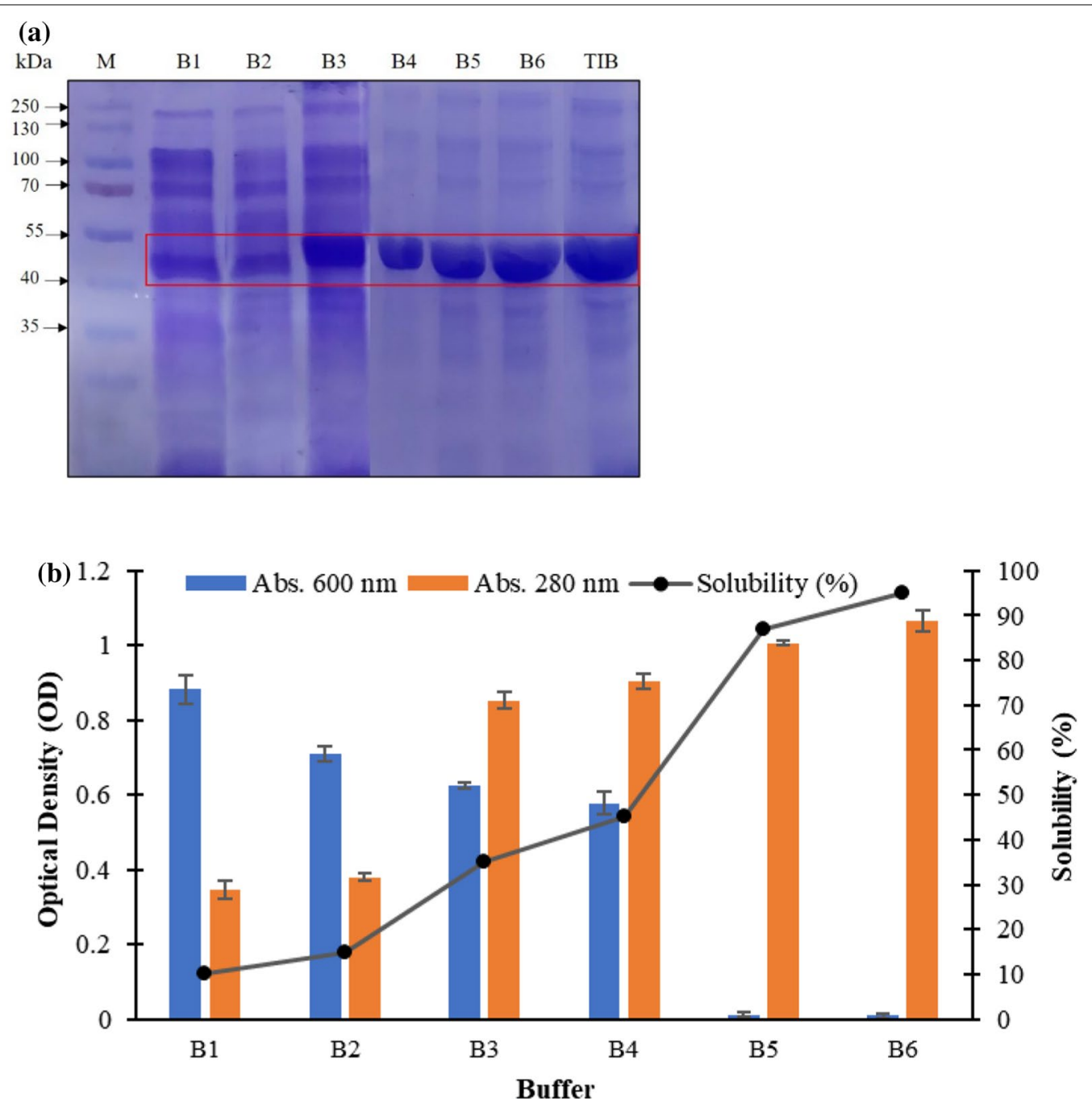

Fig. 3 Solubilization of rMtCel6A purified IBs using different solubilization buffers a SDS gel of solubilized IBs; M: protein marker; B1: Buffer 1, B2: Buffer 2, B3: Buffer 3, B4: Buffer 4, B5: Buffer 5, B6: Buffer 6 (composition as described in text), TIB: Total Inclusion Bodies [Protein ladder (PageRuler prestained) was procured from Thermo Scientific] b Graph showing \% solubility and absorbance of solubilized IBs at $600 \mathrm{~nm}$ and $280 \mathrm{~nm}$ showing turbidity, protein content, respectively

Table 1 Purification profile of rMtCel6A

\begin{tabular}{|c|c|c|c|c|c|}
\hline Fraction of MtCel6A & $\begin{array}{l}\text { Total enzyme } \\
\text { activity (U) }\end{array}$ & $\begin{array}{l}\text { Total protein } \\
\text { concentration (mg) }\end{array}$ & $\begin{array}{l}\text { Specific enzyme activity } \\
\left(\mathrm{U} \mathrm{mg}^{-1}\right)\end{array}$ & Yield (\%) & $\begin{array}{l}\text { Purification } \\
\text { (fold) }\end{array}$ \\
\hline Pure IBs & 3000 & 35 & 85 & 100 & 1 \\
\hline Soluble IBs & 2600 & 21 & 124 & 87 & 1.45 \\
\hline Refolded IBs & 1920 & 12.5 & 153 & 64 & 1.8 \\
\hline His-Tag column purified & 1720 & 10 & 172 & 57 & 2.0 \\
\hline
\end{tabular}

\section{Effect of various modulators}

In the presence of most of the metal ions $\left(\mathrm{Na}^{+}, \mathrm{Ca}^{2+}\right.$, $\left.\mathrm{K}^{+}, \mathrm{Mg}^{2+}, \mathrm{Fe}^{2+}, \mathrm{Zn}^{2+}, \mathrm{NH}_{4}^{+}\right)$tested, the rMtCel6A retains $>80 \%$ activity. While three metal ions $\left(\mathrm{Co}^{2+}\right.$,
$\mathrm{Mn}^{2+}$ and $\mathrm{Cu}^{2+}$ ) exerted stimulatory effect with 113 , 114 and $110 \%$ of relative activity (Table 3 ). The presence of solvents such as acetone, ethanol, liquor ammonia, isoamyl-alcohol and hexane at $10 \%$ concentration 

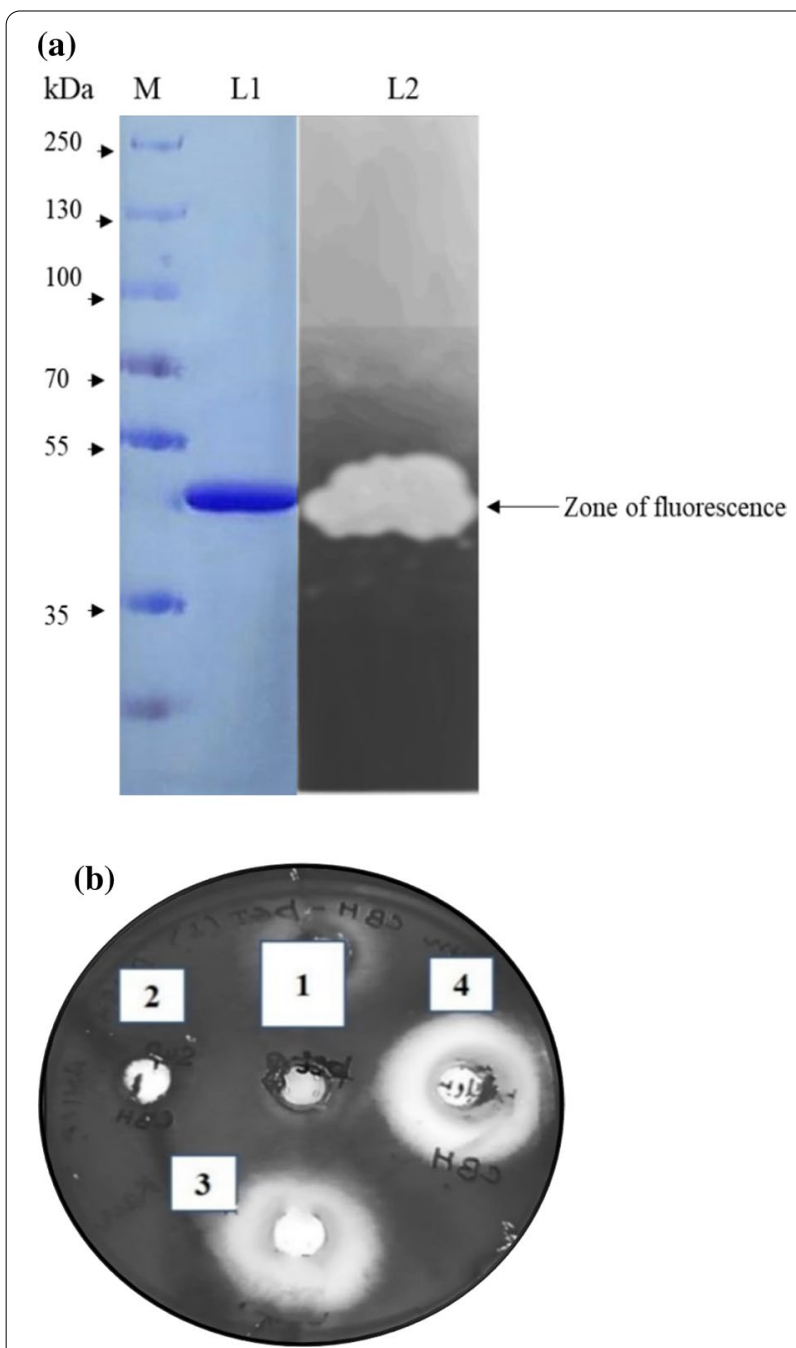

Fig. 4 a Purification and zymogram of rMtCel6A. M: protein marker, L1: purified rMtCel6A, L3: zymogram showing fluorescence [Protein ladder (PageRuler Plus prestained) was procured from Thermo Scientific] b Qualitative cellobiohydrolase assay of various fractions of rMtCel6A using 4-MUC as substrate, where well 1: negative control (pH 10 buffer only), well 2: supernatant fraction obtained after lysis of rMtCel6A; well 3: rMtCel6A pure IBs (unfolded); well 4: solubilized and refolded IBs of rMtCel6A

Table 2 Substrate specificities of rMtCel6A

\begin{tabular}{lll}
\hline Substrate & $\begin{array}{l}\text { Specific activity (U } \\
\mathbf{m g}^{-1} \text { ) }\end{array}$ & $\begin{array}{l}\text { Relative } \\
\text { enzyme } \\
\text { activity (\%) }\end{array}$ \\
\hline Avicel PH-101 & 172 & 100 \\
Crystalline cellulose & 160 & 93 \\
Filter paper & 146 & 85 \\
Cotton & 112 & 65 \\
Wheat bran & 103 & 60 \\
CMC & ND & ND \\
Birchwood xylan & ND & ND \\
\hline
\end{tabular}

ND Not detected stimulated rMtCel6A enzyme activity. More than $90 \%$ of enzyme activity was retained in the presence of chloroform and isopropanol, while the enzyme was completely denatured in the presence of ethyl-acetate. Butanol and methanol displayed no observable effect on rMtCel6A activity (Table 3). The enzyme is surfactant/detergent tolerant retaining $>75 \%$ of residual enzyme activity in the presence of surfactants like SDS, triton X-100, CTAB and PEG (Table 3). The presence of tween-80, however, displayed inhibition (33\%). The effect of cationic surfactant CTAB is unfavourable with $78 \%$ residual enzyme activity in comparison with anionic surfactant (SDS), where residual enzyme activity is $86 \%$. In the presence of WRK, EDAC and NBS, the enzyme activity was inhibited to a varied extent (Table 3).

\section{Salt tolerance}

The rMtCel6A was active in the presence of $1-2 \mathrm{M} \mathrm{NaCl}$, and it declined on further increasing $\mathrm{NaCl}$ concentration and complete loss of enzyme activity was observed at 2.5 and $3 \mathrm{M} \mathrm{NaCl}$. The enzyme retained $89 \%$ activity at $0.5 \mathrm{M}$ $\mathrm{NaCl}$, which declined to $77 \%$ at $2 \mathrm{M} \mathrm{NaCl}$ [Fig. $5 \mathrm{~d}$ ].

\section{Applicability of rMtCel6A in saccharification of pre-treated sugarcane bagasse \\ End-products analysis and synergistic effect of MtCel6A with commercial cellulase cocktail (Cellic CTec2)}

The final product of sugarcane bagasse hydrolysis was mainly a disaccharide, cellobiose [Fig. 6a]. The amount of oligosaccharide products released from the biomass gradually increased in a time dependent manner. The release of sugars was observed in the hydrolysates, when rMtCel6A was used in combination with cellulosic enzyme cocktail (Cellic CTec2) [Fig. 6b]. After $6 \mathrm{~h}$ of hydrolysis, a marked increase in reducing sugar yield was attained in the hydrolysates, when the blend of both enzymes were used in comparison with those attained by Cellic CTec2 and rMtCel6A alone [Fig. 6c]. The degree of synergy between rMtCel6A and Cellic CTec2 was 1.2 with a marked increase in relative saccharification to 194\% (Table 4).

\section{Discussion}

A recombinant MtCel6A (GH6) cellobiohydrolase of $M$. thermophila has been heterologously expressed and characterized for the first time. The 3D model of MtCel6A suggests to contain 7-stranded $(\beta / \alpha)$ barrel fold and a tunnel shape catalytic site, which is a key structural feature of Cel6A family of enzymes (Varrot et al. 1999). Multiple sequence alignment suggests that Asp residues are critical in enzyme catalysis. Earlier investigations revealed that the identification of catalytic base is less certain in Cel6A. Asp 128 (proton donor) of MtCel6A 

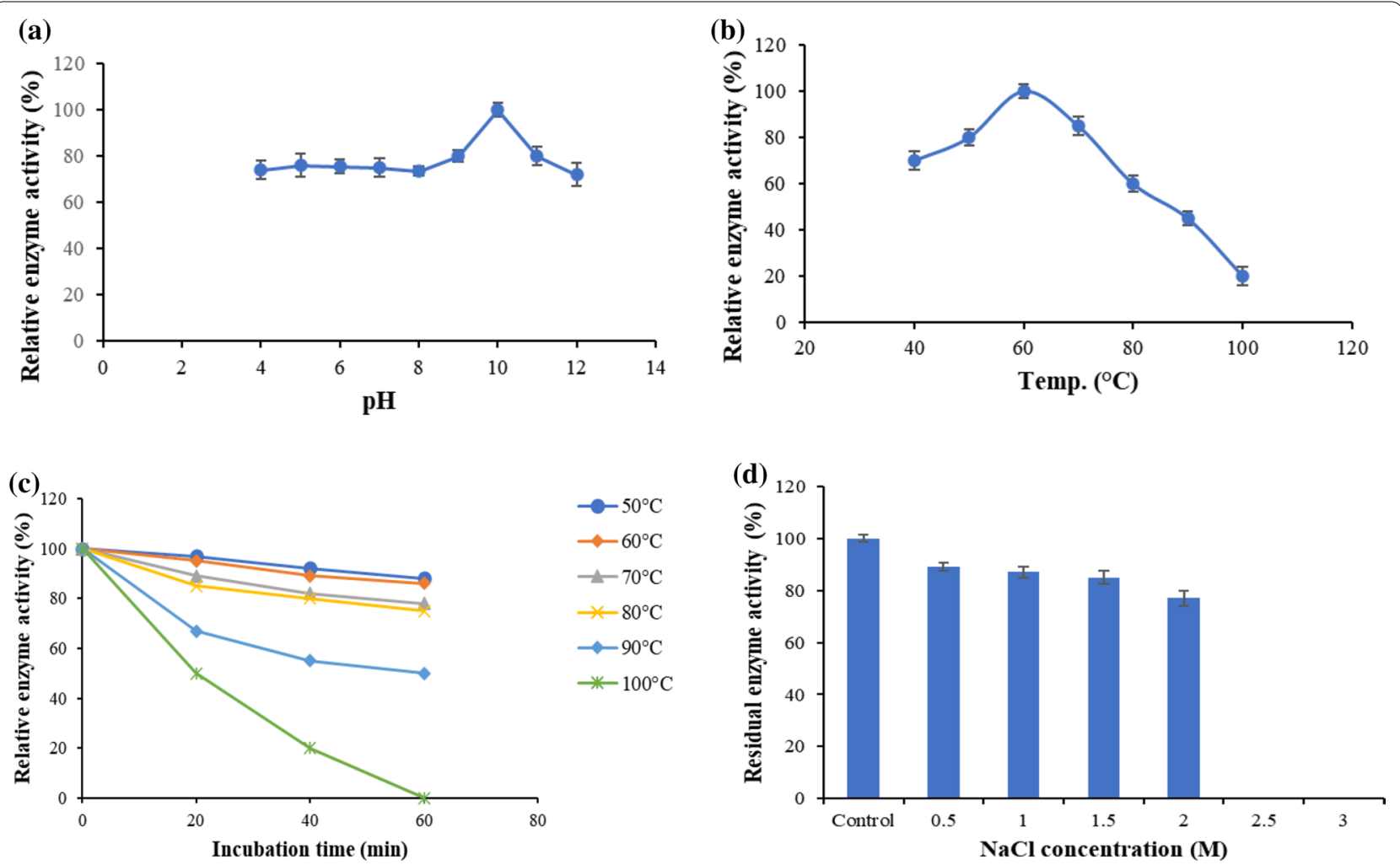

Fig. 5 Effect of $\mathbf{a} \mathrm{pH}$, and $\mathbf{b}$ temperature on rMtCel6A activity, $\mathbf{c}$ Thermostability of rMtCel6A, $\mathbf{d}$ Effect of $\mathrm{NaCl}$ on rMtCel6A activity

Table 3 Effect of various additives on rMtCel6A activity

\begin{tabular}{|c|c|c|c|}
\hline Additives & $\begin{array}{l}\text { Residual } \\
\text { rMtCel6A } \\
\text { activity (\%) }\end{array}$ & Additives & $\begin{array}{l}\text { Residual } \\
\text { rMtCel6A } \\
\text { activity (\%) }\end{array}$ \\
\hline Control & $100 \pm 1.09$ & Control & $100 \pm 1.09$ \\
\hline Metal ions & $5 \mathrm{mM}$ & Surfactants & $0.5 \%$ \\
\hline $\begin{array}{l}\mathrm{Na}^{+} \\
\mathrm{Ca}^{2+} \\
\mathrm{Co}^{2+} \\
\mathrm{K}^{+} \\
\mathrm{Mg}^{2+} \\
\mathrm{Mn}^{2+} \\
\mathrm{Fe}^{2+} \\
\mathrm{Cu}^{2+} \\
\mathrm{Zn}^{2+} \\
\mathrm{NH}^{+}\end{array}$ & $\begin{array}{l}90 \pm 1.20 \\
88 \pm 0.90 \\
113 \pm 1.24 \\
94 \pm 1.31 \\
97 \pm 0.90 \\
114 \pm 1.40 \\
84 \pm 1.52 \\
110 \pm 0.79 \\
81 \pm 0.99 \\
89 \pm 2.01\end{array}$ & $\begin{array}{l}\text { SDS } \\
\text { Tween-80 } \\
\text { Triton X-100 } \\
\text { CTAB } \\
\text { PEG }\end{array}$ & $\begin{array}{l}86 \pm 2.09 \\
67 \pm 1.97 \\
91 \pm 1.76 \\
78 \pm 1.39 \\
80 \pm 1.80\end{array}$ \\
\hline Organic solvents & $10 \%$ & Modulators & $5 \mathrm{mM}$ \\
\hline $\begin{array}{l}\text { Acetone } \\
\text { Butanol } \\
\text { Chloroform } \\
\text { Ethanol } \\
\text { Ethyl acetate } \\
\text { Hexane } \\
\text { Isoamyl-alcohol } \\
\text { Iso-propanol } \\
\text { Liquor ammonia } \\
\text { Methanol }\end{array}$ & $\begin{array}{l}137 \pm 1.67 \\
100 \pm 1.73 \\
94 \pm 1.70 \\
103 \pm 0.96 \\
\text { ND } \\
118 \pm 1.29 \\
133 \pm 1.87 \\
98 \pm 1.57 \\
120 \pm 1.26 \\
100 \pm 1.05\end{array}$ & $\begin{array}{l}\text { IA } \\
\text { DEPC } \\
\text { DTT } \\
\text { EDAC } \\
\text { EDTA } \\
\text { NBS } \\
\text { PMSF } \\
\text { WRK }\end{array}$ & $\begin{array}{l}50 \pm 1.80 \\
70 \pm 1.69 \\
60 \pm 0.97 \\
40 \pm 1.54 \\
62 \pm 1.04 \\
45 \pm 1.45 \\
75 \pm 1.28 \\
25 \pm 2.01\end{array}$ \\
\hline
\end{tabular}

ND Not detected corresponds to Asp 226 and Asp 221 of Cel6A of H. insolens and T. reesei, respectively (Varrot et al. 1999; Rouvinen et al. 1990). Trp residues 273 and 276 are known to interact with the glucose sugar rings (Rouvinen et al. 1990; Varrot et al. 1999). Two conserved cysteine residues (Cys 313 and Cys 316) have been considered to stabilize the loops involved in the formation of active site tunnel (Rouvinen et al. 1990). Other conserved residues have also been identified, which could be critical in substrate binding, catalysis and thermostability.

The rMtCel6A is produced in the form of IBs in E. coli. These IBs are solubilized using mild solubilizing agents that help in restoration of the native like secondary structure of the protein and in the recovery of bioactive protein (Singh et al. 2015). The mild solubilizing agents either have a high $\mathrm{pH}$ or high salinity, and are devoid of any denaturants. The presence of enzyme activity in unfolded protein depicts that $\mathrm{rMtCel6A}$ is not completely inactive even in the form of IBs. It has been reported earlier that some non-classical IBs are active as they possesses a large amount of properly folded target protein (Singhvi et al. 2020). Therefore, rMtCel6A is thus expressed in the form of non-classical IBs in E. coli. Refolding, however, led to an enhancement in enzyme activity. 

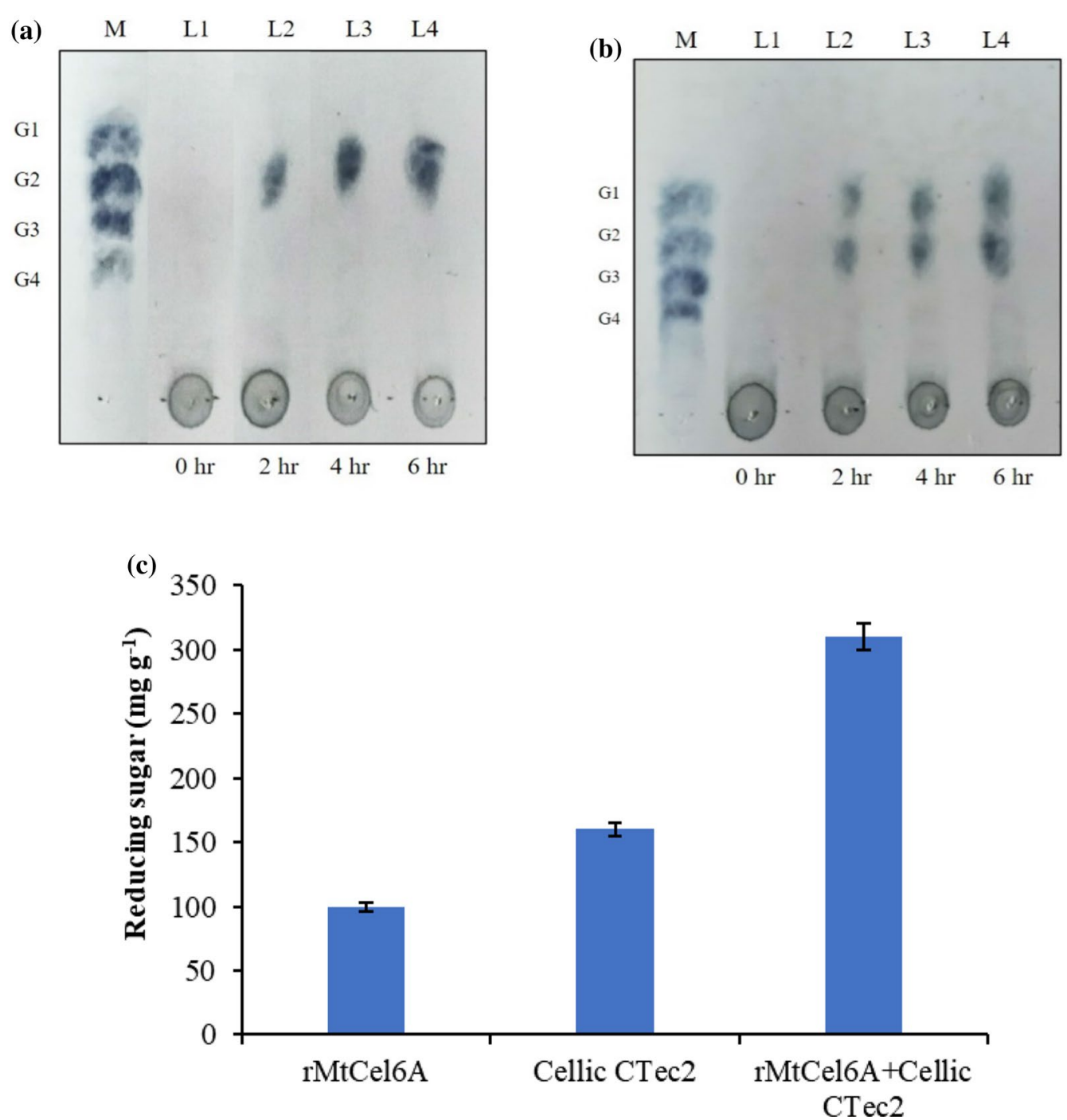

Fig. 6 End product analysis of sugarcane bagasse hydrolysis by TLC; where M shows sugar standards and L1-L4 show the hydrolytic products obtained in regular time intervals a rMtCel6 A alone b rMtCel6A + Cellic CTec2 c Reducing sugars liberated after hydrolysis of sugarcane bagasse utilizing Cellic CTec2, rMtCel6A and their combination

Table 4 Saccharification profile of rMtCel6A in combination with Cellic CTec2

\begin{tabular}{lllll}
\hline Enzymes & $\begin{array}{l}\text { Reducing sugar liberated } \\
\left(\mathbf{m g ~ g}^{-1}\right)\end{array}$ & \% Saccharification & \% Relative saccharification & $\begin{array}{l}\text { Degree of } \\
\text { synergy } \\
\text { (DOS) }\end{array}$ \\
\hline Cellic CTec2 (Control) & $160 \pm 0.8$ & 36 & 100 & $\mathrm{NA}$ \\
rMtCel6A & $100 \pm 1.2$ & 22.5 & 62.5 & $\mathrm{NA}$ \\
rMtCel6A+Cellic CTec2 & $310 \pm 1.8$ & 70 & 194 & 1.2 \\
\hline
\end{tabular}

NA Not applicable

The prediction of rMtCel6A secondary structure based on the CD spectra is consistent with the previous reports that Cel6A of Trichoderma reesei displays an approximately similar proportion of $35.8 \% \alpha$-helices and $8.7 \%$ $\beta$-strands. In contrast, a cellobiohydrolase of A. fumigatus strain (AfCel6A) contained 27\% $\alpha$-helix and 7.7\% $\beta$-strands (Bernardi et al. 2021). The presence of intact $\beta$-strands and a decline in random coils in the refolded 
Table 5 The characteristics of fungal cellobiohydrolases

\begin{tabular}{|c|c|c|c|c|c|c|c|}
\hline Protein & GH family & $\begin{array}{l}\text { Source } \\
\text { organism }\end{array}$ & $\begin{array}{l}\text { Molecular } \\
\text { mass }(\mathrm{kDa})\end{array}$ & $\begin{array}{l}\text { Enzyme } \\
\text { activity }\end{array}$ & $\begin{array}{l}\text { Optimum pH } \\
\text { and Temp. } \\
\left({ }^{\circ} \mathrm{C}\right)\end{array}$ & Enzyme kinetics & Reference \\
\hline MtCel6A & 6 & $\begin{array}{l}\text { Myceliophthora } \\
\text { thermophila }\end{array}$ & $\sim 45$ & $172 \mathrm{U} \mathrm{mg}^{-1}$ & 10 and 60 & $\begin{array}{l}\mathrm{K}_{\mathrm{m}}=3.2 \mathrm{mg} \mathrm{mL}^{-1} \\
\mathrm{~V}_{\text {max }}=222.2 \mu \mathrm{Mg} \mathrm{m}^{-1} \mathrm{~min}^{-1}\end{array}$ & This investigation \\
\hline TICel6A & 6 & $\begin{array}{l}\text { Talaromyces } \\
\text { leycettanus }\end{array}$ & 65 & $92.9 \mathrm{U} \mathrm{mg}^{-1}$ & 5 and 80 & NR & Gu et al. 2019 \\
\hline Ctcel6 & 6 & $\begin{array}{l}\text { Chaetomium } \\
\text { thermophilum }\end{array}$ & 42 & $1.27 \mathrm{U} \mathrm{mg}^{-1}$ & 5 and 70 & $\mathrm{~K}_{\mathrm{m}}=0.30 \mathrm{mM}$ & Zhou et al. 2017 \\
\hline CelA & 6 & $\begin{array}{l}\text { Neocallimastix } \\
\text { patriciarum J11 }\end{array}$ & 55 & $200 \mathrm{U} \mathrm{mg}^{-1}$ & 6 and 50 & NR & Wang et al. 2014 \\
\hline $\mathrm{CBH} 1$ and $\mathrm{CBH} 2$ & NR & $\begin{array}{l}\text { Schizophyl- } \\
\text { lum commune } \\
\text { KMJ820 }\end{array}$ & 50 and 150 & $\begin{array}{l}\text { 19.57and } 18.12 \\
\text { U mg }\end{array}$ & 5 and 50 & $\begin{array}{l}\mathrm{K}_{\mathrm{m}}=2.0 \mathrm{mM} \text { and } 1.4 \mathrm{mM} \\
\mathrm{V}_{\max }=51.4 \text { and } 20.8 \mathrm{U} \mathrm{mg}^{-1}\end{array}$ & $\begin{array}{l}\text { Kondaveeti et al. } \\
2020\end{array}$ \\
\hline CtCel7 & 7 & $\begin{array}{l}\text { Chaetomium } \\
\text { thermophilum }\end{array}$ & 73 & $1.94 \mathrm{U} \mathrm{mg}^{-1}$ & 4 and 60 & $\begin{array}{l}\mathrm{K}_{\mathrm{m}}=4 \mathrm{mg} \mathrm{mL}^{-1} \\
\mathrm{~V}_{\max }=18.45 \mathrm{ug} \mathrm{min}^{-1} \mathrm{~mL}^{-1} \\
\mathrm{~K}_{\text {cat }} / \mathrm{K}_{\mathrm{m}}=391 \mathrm{~mL} \mathrm{~s}^{-1} \mathrm{mg}^{-1}\end{array}$ & Han et al. 2020 \\
\hline $\mathrm{CBHI}$ & 7 & $\begin{array}{l}\text { Penicillium } \\
\text { digitatum }\end{array}$ & 74 & $30.9 \mathrm{U} \mathrm{mg}^{-1}$ & 5.2 and 60 & $\begin{array}{l}\mathrm{K}_{\mathrm{m}}=11.2 \mathrm{mg} \mathrm{mL}^{-1} \\
\mathrm{~V}_{\max }=0.13 \mu \mathrm{mol} \mathrm{min}^{-1} \\
\mathrm{~K}_{\mathrm{cat}} / \mathrm{K}_{\mathrm{m}}=4.7\left(\mathrm{mg} \mathrm{mL}^{-1}\right)^{-1} \mathrm{~s}^{-1}\end{array}$ & $\begin{array}{l}\text { Dos Santos et al. } \\
2020\end{array}$ \\
\hline Cbh1 & 7 & $\begin{array}{l}\text { Trichoderma } \\
\text { virens UKM1 }\end{array}$ & 54 & $4.195 \mathrm{U} \mathrm{mg}^{-1}$ & 4 and 60 & $\begin{array}{l}\mathrm{K}_{\mathrm{m}}=1.88 \mathrm{mM} \\
\mathrm{V}_{\max }=41.6 \mu \text { mole } \\
\mathrm{min}^{-1} \mathrm{mg}^{-1} \\
\mathrm{~K}_{\mathrm{cat}} \mathrm{t} \\
\mathrm{K}_{\mathrm{m}}=5.68 \times 10^{-4} \mathrm{mM}^{-1} \mathrm{~s}^{-1}\end{array}$ & Wahab et al. 2019 \\
\hline Te-Cel7A & 7 & $\begin{array}{l}\text { Trichoderma } \\
\text { reesei }\end{array}$ & 66 & $0.93 \cup L^{-1}$ & 5 and 65 & NR & Sun et al. 2018 \\
\hline MtCel7A & 7 & $\begin{array}{l}\text { Myceliophthora } \\
\text { thermophila }\end{array}$ & 66 & $6.8 \mathrm{U} \mathrm{mg}^{-1}$ & $4-5$ and 70 & $\begin{array}{l}\mathrm{K}_{\mathrm{m}}=0.57 \mathrm{mM} \\
\mathrm{k}_{\mathrm{cat}} / \mathrm{K}_{\mathrm{m}}=6.7 \mathrm{M}^{-1} \mathrm{~s}^{-1}\end{array}$ & $\begin{array}{l}\text { Kadowaki et al. } \\
2018\end{array}$ \\
\hline $\mathrm{CBH} 7 \mathrm{~B}$ & 7 & $\begin{array}{l}\text { Thielavia ter- } \\
\text { restris }\end{array}$ & 51.8 & $63 \mathrm{U} \mathrm{mg}^{-1}$ & 5 and 55 & 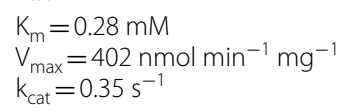 & Woon et al. 2016 \\
\hline
\end{tabular}

$N R$ Not reported

IBs of MtCel6A confirms restoration of its secondary structure during the refolding process. The $\mathrm{CD}$ spectra of rMtCel6A showed a positive peak from $200-210 \mathrm{~nm}$ and a broad negative peak near $210 \mathrm{~nm}$ which extended till $240 \mathrm{~nm}$, suggesting the dominance of $\alpha$-helices in the secondary structure of MtCel6A.

The crystalline cellulose is the substrate preference of CBHs and this enzyme activity is a vital step in cellulose degradation (Lynd et al. 2002). In contrast, CMC is a soluble substrate and is usually not hydrolyzed by $\mathrm{CBHs}$ (Tonozuka et al. 2014). The observations recorded in this investigation are in agreement with this feature; no activity of rMtCel6A was detected on CMC. This could be explained by the fact that the catalytic site of MtCel6A is typically enclosed by a tunnel shape structure which does not allow soluble substrate like CMC to access the active site (Varrot et al. 1999). Thus, observations further suggest that this is a processive enzyme containing highest exo-catalytic activity on crystalline cellulose. The specific activity of this enzyme on avicel is higher than those reported for other CBHs (Dos Santos et al. 2020; Gu et al.
2019) making it an efficient Cbh. The rMtCel6A specifically attacks $\beta$-1,4-glycosidic bonds from the non-reducing ends of the crystalline cellulose and is remarkable in hydrolyzing a diverse range of polysaccharides containing $\beta$-1,4-linkages; this conclusion is based on the fact that $\mathrm{Cel} 6 \mathrm{CBHs}$ act from non-reducing ends of cellulose (Rouvinen et al. 1990).

Most of the GH6 cellulases are optimally active in the acidic range such as Ctcel6 of Chaetomium thermophilum and TlCel6A of Talaromyces leycettanus (Zhou et al. 2017; Gu et al. 2019) and also GH7 CBHs of $M$. thermophila (MtCel7A) and C. thermophilum (CtCel7) (Kadowaki et al. 2018; Han et al. 2020). Only one CBH (MoCel6A) of Magnaporthe oryzae has been reported with the pH optima of 9.0 (Takahashi et al. 2010). It is known that a high $\mathrm{pH}$ causes reduction in $\mathrm{CBH}$ adsorption to lignin during enzymatic hydrolysis ( $\mathrm{Lu}$ et al. 2017), thus a high pH optima of rMtCel6A is a beneficial feature for some industrial applications too. The temperature optimum of this recombinant enzyme is $60{ }^{\circ} \mathrm{C}$. Most characterized $\mathrm{CBHs}$ have been shown to be 
active in this temperature range (Table 5). Thermostability studies validate that this enzyme is a thermostable enzyme. Another $\mathrm{CBH}$ of this strain (rMtCel7A) is reported to be less thermostable with the $T_{1 / 2}$ of $60 \mathrm{~min}$ at $70{ }^{\circ} \mathrm{C}$ as compared to that of rMtCel6A that exhibits prolonged activity at $70{ }^{\circ} \mathrm{C}$ (Kadowaki et al. 2018).

The $\mathrm{K}_{\mathrm{m}}$ value of this enzyme is lower than those of other reported fungal CBHs (Han et al. 2020; Dos Santos et al. 2020), suggesting that it has a higher substrate affinity and possesses a superior catalytic activity. It is known that Cel6A (CBHII) of Hypocrea jecorina is more effective when substrate is abundant, while Cel7A (CBHI) works efficiently when substrate is limiting (Badino et al. 2017). Cel6A is, therefore, an efficient enzyme in cellulose degradation and is able to release a higher amount of cellobiose at much higher rate than Cel7A. Both CBHI and CBHII are produced by cellulolytic fungi in order to efficiently hydrolyze cellulose (Tonozuka et al. 2014).

The enzyme activity of rMtCel6A in the presence of metal ions is comparable with the $\mathrm{CBH}$ of Clostridium clariflavum and Trichoderma harzianum; stimulation in enzyme activity was observed in the presence of $\mathrm{Cu}^{2+}$ and $\mathrm{Co}^{2+}$ ions (Zafar et al. 2021; Nawaz et al. 2006). The activity of $\mathrm{CBH}$ of Neocallimastix patriciarum J11 was stimulated by $\mathrm{Co}^{2+}, \mathrm{Mn}^{2+}$ and $\mathrm{Cu}^{2+}$ (Wang et al. 2014). Metal ions act as electrophiles and are vital in increasing substrate polarity and the rate of enzyme catalysis by interacting with certain amino acid residues in the active sites of enzymes (Siegel and Siegel 1976). It is evident that rMtCel6A is an organic solvent tolerant cellulase which is a desirable characteristic feature for one-pot production of biofuels. Various industrial processes usually require enzymes to be active in the presence of organic solvents, in which most enzymes often lose their activity (Chapman et al. 2018). Many thermostable enzymes are known to display organic solvent tolerance due to the presence of relatively higher proportion of hydrophobic amino acids (Vieille and Zeikus 2001). rMtCel6A is also a surfactant tolerant enzyme that proves its potential application in the detergent formulations. The stability in the presence of non-ionic surfactants has greater advantages in industrial applications including paper industries. Agrawal et al. (2017) reported that the addition of surfactant during enzymatic hydrolysis is an effective way to improve saccharification.

Previous studies have suggested that an Asp residue is the probable catalytic residue of Cel6A that plays a crucial role in the substrate binding (Rouvinen et al. 1990), which further confirms the observations recorded in this investigation. The reduced activity in presence of WRK, EDAC and NBS predicts the existence of acidic and aromatic amino acid residues and carboxylic groups in the active site of MtCel6A. Trp residues have also been reported to be located at the entrance of the active site tunnel of GH6 CBH of Phanerochaete chrysosporium (Yamaguchi et al. 2020). The presence of the Trp residue provides hydrophobic stacking interactions and guide the cellulose chain into the active site tunnel for hydrolytic action (Nakamura et al. 2013). The presence of Asp residues in the catalytic cite of enzyme also confirms that acidic amino acid residues and carboxylic groups are critical in enzyme catalysis. Multiple sequence alignment also validates the significant role of these residues in MtCel6A.

The rMtCel6A also showed salt tolerance with minimal effect of $\mathrm{NaCl}$ (upto $2 \mathrm{M}$ ) on rMtCel6A activity. The halostability is not reported in other two characterized CBHs of M. thermophila (Gusakov et al. 2005; Kadowaki et al. 2018). Thus, this is the first halostable $\mathrm{CBH}$ reported in $M$. thermophila.

It is identified that GH6 CBHs are classically exotype CBHs acting from non-reducing ends (Varrot et al. 1999; Rouvinen et al. 1990). Thus, the end product

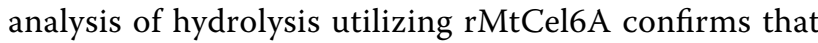
this enzyme displays exo-catalytic action with the liberation of cellobiose. The inclusion of rMtCel6A in Cellic $\mathrm{CTec} 2$ for hydrolysis suggests that rMtCel6A exerts a synergistic effect leading to enhanced saccharification of the complex cellulosic biomass such as sugarcane bagasse.

This investigation suggests that rMtCel6A exhibits remarkable thermo-alkali stability with detergent and solvent tolerance that makes this $\mathrm{CBH}$ useful in various biotechnological processes, where high temperature, alkaline conditions, detergents and solvents prevail. The enzyme activity of rMtCel6A in the presence of a wide range of substrates suggests that this is a processive enzyme with a typical exocellulase activity. The presence of $\mathrm{CBHI}$ and $\mathrm{CBHII}$ makes the cellulolytic system robust and efficient. The synergistic effect of MtCel6A with commercial cellulases supports its utility in the saccharification of lignocellulosics and bioconversion of cellulosics to bioethanol.

\section{Supplementary Information}

The online version contains supplementary material available at https://doi. org/10.1186/s13568-021-01311-8.

Additional file 1: Fig. S1. CD Spectra of rMtCel6A depicting secondary structure of refolded and unfolded IBS.

Acknowledgements

Research Fellowship granted to AD by Netaji Subhas Institute of Technology (India) is gratefully acknowledged. The authors thank Central Instrumentation Facility at the University Delhi, South Campus, New Delhi (India) for expending help in CD spectral studies. 


\section{Authors' contributions}

TS conceived the research theme. TS and AD designed experiments. AD conducted experiments, analyzed the data and prepared the initial manuscript. SS and TS read the manuscript critically and improved it further. All authors read and approved the final manuscript.

\section{Funding}

This research was partially funded by Indo-US Science and Technology Forum (IUSSTF) and Department of Biotechnology (DBT), Government of India and the University Grants Commission (UGC), New Delhi (India).

\section{Availability of data and materials}

All data generated or analyzed during this study are included in this manuscript.

\section{Declarations}

Ethics approval and consent to participate

This article does not contain any studies that involve human participants or animals.

\section{Consent for publication}

Not applicable.

\section{Competing interests}

The authors declare no competing interests.

\section{Author details}

${ }^{1}$ Department of Biological Sciences \& Engineering, Netaji Subhas Institute of Technology (University of Delhi), Azad Hind Fauj Marg, Sector-3 Dwarka, New Delhi 110078, India. ${ }^{2}$ Department of Biological Sciences \& Engineering, Netaji Subhas University of Technology, Azad Hind Fauj Marg, Sector-3 Dwarka, New Delhi 110078, India.

Received: 16 October 2021 Accepted: 29 October 2021

Published online: 04 November 2021

\section{References}

Agrawal R, Satlewal A, Kapoor M, Mondal S, Basu B (2017) Investigating the enzyme-lignin binding with surfactants for improved saccharification of pilot scale pretreated wheat straw. Bioresour Technol 224:411-418

Ali I, Asghar R, Ahmed S, Sajjad M, Tariq M, Waheed Akhtar M (2015) mRNA secondary structure engineering of Thermobifida fusca endoglucanase (Cel6A) for enhanced expression in Escherichia coli. World J Microbiol Biotechnol 31:499-506

Anderson K, Li SC, Li YT (2000) Diphenylamine-aniline-phosphoric acid reagent, a versatile spray reagent for revealing glycoconjugates on thin-layer chromatography plates. Anal Biochem 287:337-339

Badino SF, Christensen SJ, Kari J, Windahl MS, Hvidt S, Borch K, Westh P (2017) Exo-exo synergy between Cel6A and Cel7A from Hypocrea jecorina: Role of carbohydrate binding module and the endo-lytic character of the enzymes. Biotechnol Bioeng 114:1639-1647

Bernardi AV, Gerolamo LE, de Gouvea PF, Yonamine DK, Pereira LMS, de Oliveira AHC, Uyemura SA, Dinamarco TM (2021) LPMO AfAA9_B and cellobiohydrolase AfCel6A from A. fumigatus boost enzymatic saccharification activity of cellulase cocktail. Int J Mol Sci 22:276

Chapman J, Ismail AE, Dinu CZ (2018) Industrial applications of enzymes: recent advances, techniques, and outlooks. Catalysts 8:2073-4344

Dadwal A, Sharma S, Satyanarayana T (2020) Progress in ameliorating beneficial characteristics of microbial cellulases by genetic engineering approaches for cellulose saccharification. Front Microbiol 11:1387

Dadwal A, Sharma S, Satyanarayana T (2021) Thermostable cellulose saccharifying microbial enzymes: Characteristics, recent advances and biotechnological applications. Int J Biol Macromol 188:226-244

Dos Santos FC, de Oliveira MAS, Seixas FAV, Barbosa-Tessmann IP (2020) A novel cellobiohydrolase I (CBHI) from Penicillium digitatum: Production, purification, and characterization. Appl Biochem Biotechnol 192:257-282
Gu Y, Zheng F, Wang Y, Su X, Bai Y, Yao B, Huang H, Luo H (2019) Characterization of two thermophilic cellulases from Talaromyces leycettanus JCM12802 and their synergistic action on cellulose hydrolysis. PLOS ONE 14:e0224803

Gundinger T, Spadiut O (2017) A comparative approach to recombinantly produce the plant enzyme horseradish peroxidase in Escherichia coli. J Biotechnol 248:15-24

Gusakov AV, Sinitsyn AP, Salanovich TN, Bukhtojarov FE, Markov AV, Ustinov BB, van Zeijlb C, Punt P, Burlingame R (2005) Purification, cloning and characterisation of two forms of thermostable and highly active cellobiohydrolase I (Cel7A) produced by the industrial strain of Chrysosporium lucknowense. Enzyme Microb Technol 36:57-69

Han C, Yang R, Sun Y, Liu M, Zhou L, Li D (2020) Identification and characterization of a novel hyperthermostable bifunctional cellobiohydrolasexylanase enzyme for synergistic effect with commercial cellulase on pretreated wheat straw degradation. Front Bioeng Biotechnol 8:296

Himmel ME, Ruth MF, Wyman CE (1999) Cellulase for commodity products from cellulosic biomass. Curr Opin Biotech 10:358-364

Horn SJ, Vaaje-Kolstad G, Westereng B, Eijsink VG (2012) Novel enzymes for the degradation of cellulose. Biotechnol Biofuels 5:45

Jong WS, Vikstrom D, Houben D, van den Berg van Saparoea HB, de Gier JW, Luirink J (2017) Application of an E. coli signal sequence as a versatile inclusion body tag. Microb Cell Fact 16:50.

Kadowaki MAS, Higasi P, de Godoy MO, Prade RA, Polikarpov I (2018) Biochemical and structural insights into a thermostable cellobiohydrolase from Myceliophthora thermophila. FEBS J 285:559-579

Kang Q, Appels L, Tan T, Dewil R (2014) Bioethanol from lignocellulosic biomass: current findings determine research priorities. Sci World J 2014:298153

Kim DY, Lee MJ, Cho HY, Lee JS, Lee MH, Chung CW, Shin DH, Rhee YH, Son KH, Park HY (2016) Genetic and functional characterization of an extracellular modular GH6 endo-beta-1,4-glucanase from an earthworm symbiont, Cellulosimicrobium funkei HY-13. Antonie Van Leeuwenhoek 109:1-12

Kondaveeti S, Patel SKS, Woo J, Wee JH, Kim SY, Al-Raoush RI, Kim IW, Kalia VC, Lee JK (2020) Characterization of cellobiohydrolases from Schizophyllum commune KMJ820. Indian J Microbiol 60:160-166

Lambertz C, Garvey M, Klinger J, Heesel D, Klose H, Fischer R, Commandeur U (2014) Challenges and advances in the heterologous expression of cellulolytic enzymes: a review. Biotechnol Biofuels 7:135

Liu Y, Nie Y, Lu X, Zhang X, He H, Pan F, Zhou L, Liu X, Ji X, Zhang S (2019) Cascade utilization of lignocellulosic biomass to high-value products. Green Chem 21:3499-3535

Lu X, Wang C, Li X, Zhao J (2017) Temperature and pH influence adsorption of cellobiohydrolase onto lignin by changing the protein properties. Bioresour Technol 245:819-825

Lynd LR, Weimer PJ, van ZyI WH, Pretorius IS (2002) Microbial cellulose utilization: fundamentals and biotechnology. Microbiol Mol Biol Rev 66:506-577

Manisha YSK (2017) Technological advances and applications of hydrolytic enzymes for valorization of lignocellulosic biomass. Bioresour Technol 245:1727-1739

Miller GL (1959) Use of dinitrosalicylic acid reagent for determination of reducing sugar. Anal Chem 31:426-428

Morgenstern I, Powlowski J, Ishmael N, Darmond C, Marqueteau S, Moisan MC, Quenneville G, Tsang A (2012) A molecular phylogeny of thermophilic fungi. Fungal Biol 116:489-502

Nakamura A, Tsukada T, Auer S, Furuta T, Wada M, Koivula A, Igarashi K, Samejima M (2013) The tryptophan residue at the active site tunnel entrance of Trichoderma reesei cellobiohydrolase Cel7A is important for initiation of degradation of crystalline cellulose. J Biol Chem 288:13503-13510

Nawaz S, Malana MA, Ikram N, Hafeez S, Ghori MI, Jamil A (2006) Kinetic study of carboxymethyl cellulase from Trichoderma harzianum. Pak J Life Soc Sci 4:15-19

Obeng EM, Adam SNN, Budiman C, Ongkudon CM, Maas R, Jose J (2017) Lignocellulases: a review of emerging and developing enzymes, systems, and practices. Bioresour Bioprocess 4:16

Palmer I, Wingfield PT (2012) Preparation and extraction of insoluble (inclusion-body) proteins from Escherichia coli. Curr Protoc Protein Sci. https:// doi.org/10.1002/0471140864.ps0603s70 
Rouvinen J, Bergfors T, Teeri T, Knowles JK, Jones TA (1990) Three-dimensiona structure of cellobiohydrolase II from Trichoderma reesei. Science 249:380-386

Siegel H, Siegel A (1976) Biological action of metal ions. Marcel Dekker, Inc., New York

Singh A, Upadhyay V, Panda AK (2015) Solubilization and refolding of inclusion body proteins. Methods Mol Biol 1258:283-291

Singhvi P, Saneja A, Srichandan S, Panda AK (2020) Bacterial inclusion bodies: a treasure trove of bioactive proteins. Trends Biotechnol 38:474-486

Slouka C, Kopp J, Spadiut O, Herwig C (2019) Perspectives of inclusion bodies for bio-based products: curse or blessing? Appl Microbiol Biotechnol 103:1143-1153

Sun N, Qian Y, Wang W, Zhong Y, Dai M (2018) Heterologous expression of Talaromyces emersonii cellobiohydrolase Cel7A in Trichoderma reesei increases the efficiency of corncob residues saccharification. Biotechnol Lett 40:1119-1126

Suresh A, Shravan Ramgopal D, Panchamoorthy Gopinath K, Arun J, SundarRajan P, Bhatnagar A (2021) Recent advancements in the synthesis of novel thermostable biocatalysts and their applications in commercially important chemoenzymatic conversion processes. Bioresour Technol 323:124558

Takahashi M, Takahashi H, Nakano Y, Konishi T, Terauchi R, Takeda T (2010) Characterization of a cellobiohydrolase (MoCel6A) produced by Magnaporthe oryzae. Appl Environ Microbiol 76:6583-6590

Teter SA, Sutton KB, Emme B (2014) Enzymatic processes and enzyme development in biorefining. In: Waldron K (ed) Advances in biorefineries. Elsevier, Amsterdam, pp 199-233

Tonozuka T, Yoshida M, Takeuchi M (2014) Enzymes for cellulosic biomass conversion. In: Tojo S, Hirasawa T (eds) Research approaches to sustainable biomass systems. Academic Press, USA, pp 225-242

Turner P, Mamo G, Karlsson EN (2007) Potential and utilization of thermophiles and thermostable enzymes in biorefining. Microb Cell Fact 6:9

Varrot A, Hastrup S, Schulein M, Davies GJ (1999) Crystal structure of the catalytic core domain of the family 6 cellobiohydrolase II, Cel6A, from Humicola insolens, at 1.92 A resolution. Biochem J 337:297-304

Vieille C, Zeikus GJ (2001) Hyperthermophilic enzymes: sources, uses, and molecular mechanisms for thermostability. Microbiol Mol Biol Rev $65: 1-43$
Wahab AFFA, Abdul Karim NA, Ling JG, Hasan NS, Yong HY, Bharudin I, Kamaruddin S, Abu Bakar FD, Murad AMA (2019) Functional characterisation of cellobiohydrolase I (Cbh1) from Trichoderma virens UKM1 expressed in Aspergillus niger. Protein Expr Purif 154:52-61

Wang HC, Chen YC, Hseu RS (2014) Purification and characterization of a cellulolytic multienzyme complex produced by Neocallimastix patriciarum J11. Biochem Biophys Res Commun 451:190-195

Waterborg JH (2009) The Lowry method for protein quantitation. In: Walker JM (ed) The protein protocols handbook. Springer Protocols Handbooks, Humana Press, Totowa, NJ, pp 7-10

Woon JS, Mackeen MM, Mahadi NM, Illias RM, Abdul Murad AM, Abu Bakar FD (2016) Expression and characterization of a cellobiohydrolase (CBH7B) from the thermophilic fungus Thielavia terrestris in Pichia pastoris. Biotechnol Appl Biochem 63:690-698

Yamaguchi S, Sunagawa N, Tachioka M, Igarashi K, Samejima M (2020) Thermostable mutants of glycoside hydrolase family 6 cellobiohydrolase from the basidiomycete Phanerochaete chrysosporium. J Appl Glycosci 67:79-86

Yin YR, Zhang F, Hu QW, Xian WD, Hozzein WN, Zhou EM, Ming H, Nie GX, Li WJ (2015) Heterologous expression and characterization of a novel halotolerant, thermostable, and alkali-stable GH6 endoglucanase from Thermobifida halotolerans. Biotechnol Lett 37:857-862

Zafar A, Aftab MN, Asif A, Karadag A, Peng L, Celebioglu HU, Afzal MS, Hamid A, labal I (2021) Efficient biomass saccharification using a novel cellobiohydrolase from Clostridium clariflavum for utilization in biofuel industry. RSC Adv 11:9246-9261

Zhou Q, Jia J, Ji P, Han C (2017) Novel application potential of GH6 cellobiohydrolase CtCel6 from thermophilic Chaetomium thermophilum for gene cloning, heterologous expression and biological characterization. Int J Agri Bio. https://doi.org/10.17957/IJAB/15.0290

\section{Publisher's Note}

Springer Nature remains neutral with regard to jurisdictional claims in published maps and institutional affiliations.

\section{Submit your manuscript to a SpringerOpen ${ }^{\circ}$ journal and benefit from:}

- Convenient online submission

- Rigorous peer review

- Open access: articles freely available online

- High visibility within the field

- Retaining the copyright to your article

Submit your next manuscript at $\boldsymbol{\nabla}$ springeropen.com 